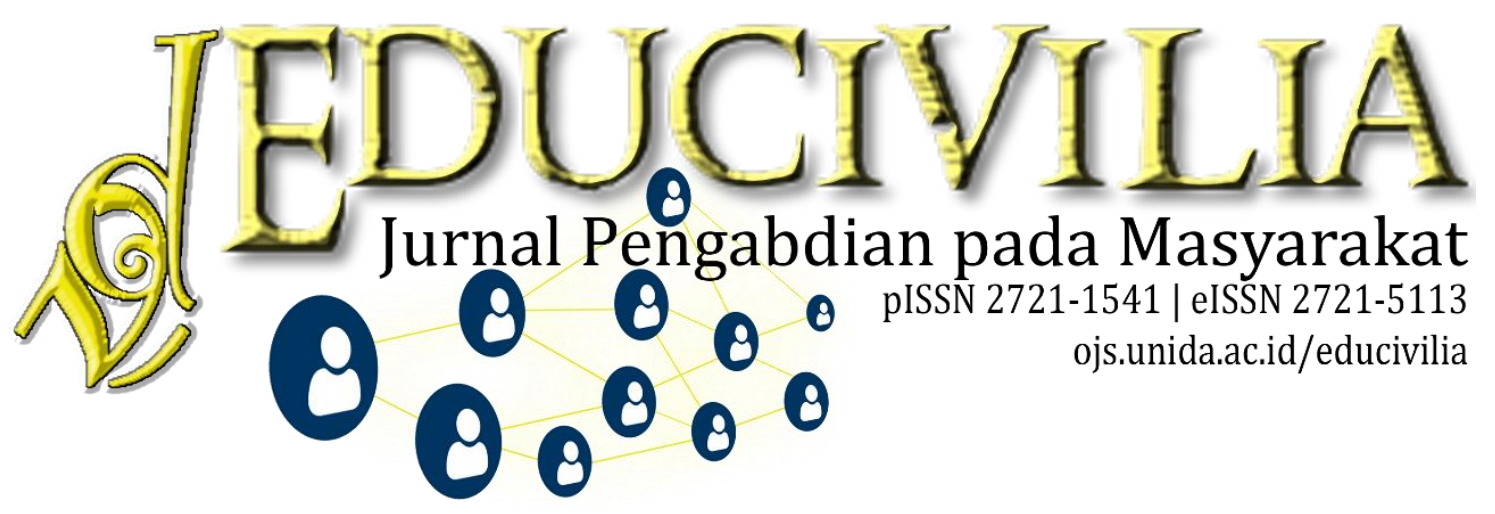

\title{
Pemeriksaan Kadar Gula Darah dan Asam Urat Lansia Pos Pengungsi Cipugur, Desa Cileuksa, Kabupaten Bogor
}

\author{
Dyah Mieta Setyawati ${ }^{1}$, Sri Hayuningsih ${ }^{2}$, Veronica Farry ${ }^{3}$, Sri Supadmini ${ }^{4}$ \\ ${ }^{123}$ Universitas Gunadarma, Jakarta, Indonesia \\ ${ }^{4}$ STIE Nusa Megarkencana, Indonesia
}

Kilas Artikel

Volume 2 Nomor 1

Januari 2021: 19-30

DOI:

10.30997/ejpm.v2i1.3109

Article History

Submission: 22-07-2020

Revised: 29-07-2020

Accepted: $24-09-2020$

Published: 25-01-2020

Kata Kunci:

Pemeriksaan Asam Urat,

Pemeriksaan Gula Darah,

Penyakit Degeneratif

Keywords:

Uric Acid Examination, Blood Sugar Examination, Degenerative Disease

Korespondensi:

(Sri Supadmini)

(s.supadmi70@gmail.com)
Abstrak

Abstrak: Puskesmas Curug menjadi pusat pelayanan terdekat dengan Pos pengungsi Cipugur merupakan mitra kegiatan pengabdian masyarakat ini. Rekam data menyebutkan bahwa terdapat 95 orang pengungsi berusia lanjut. Identifikasi permasalahan ditemukan bahwa Puskesmas Curug memiliki sumber daya terbatas tenaga pelayanan medis untuk kegiatan deteksi dini kesehatan pengungsi berusia lanjut pasca bencana alam yang terjadi pada bulan Januari 2020. Penyuluhan dan pelayanan kesehatan menjadi metode kegiatan ini. Pemeriksaan kadar gula darah dan asam urat melalui tes darah dapat digunakan untuk mendeteksi penyakit degeneratif yang muncul seiring bertambahnya usia akibat dari penurunan fungsi organ tubuh. Hasil kegiatan menunjukkan 56 orang lansia memiliki hasil pemeriksaan gula darah sewaktu dan asam urat yang lebih tinggi. Hasil kegiatan menunjukkan 56 orang lansia memiliki hasil pemeriksaan gula darah sewaktu dan asam urat yang lebih tinggi. Hasil kegiatan pengabdian kepada masyarakat ini sangat membantu puskesmas Curuk untuk mendeteksi penyakit yang muncul sehingga penanganan dapat segera diambil tindakan dengan menyediakan berbagai obat yang dibutuhan bagi pengungsi lanjut usia khususnya dan masyarakat Desa Cileuksa pada umumnya..

Examination of Blood Sugar and Urid Acid in Cipugur Refugees, Cileuksa Village, Bogor District

Abstract: Curug Puskesmas is the closest service center to the Cipugur refugee post, which is a partner of research and community service activities. Data records indicate that there were 95 elderly refugees. Identification of the problem was found that the Curug Puskesmas had limited resources for medical service personnel for the early detection of elderly refugee health services after the natural disaster that occurred in January 2020. Counseling and health services became the method of this activity. Examination of blood sugar and uric acid levels through blood tests can be used to detect degenerative diseases that appear with age due to decreased organ function. The results of the activity show that 56 elderly people have higher blood sugar and uric acid examination results. The results of 
the activities can be used as a basis for Curug Puskesmas to provide medicines for the right degenerative diseases for the elderly.

\section{PENDAHULUAN}

Hujan deras dan angin kencang yang mengguyur Jabodetabek selama dua hari yaitu Selasa sore tanggal 31 Desember 2019 hingga hingga Rabu siang tanggal 1 Januari 2020 mengakibatkan banjir dan longsor. Pos pengungsi Cipugur, Desa Cileuksa dibangun oleh Pemerintah wilayah Kabupaten Bogor sebagai relokasi masyarakat yang terkena dampak banjir dan tanah longsor tanggal 8 Januari 2020 di Kampung Rancanangka dan Kampung Cipugur. Berdasarkan data Puskemas Curug, Desa Cileuksa, Kecamatan Sukajaya, Kabupaten Bogor menjadi desa terisolir akibat longsor dan memerlukan bantuan darurat sebanyak 201 KK (726 Jiwa) terdampak bencana longsor. (Nurbowo, 2020)

Lembaga Pengabdian Pada Masyarakat Universitas Gunadarma (LPM UG) bersama 18 Dosen yang terdiri dari berbagai fakultas dan dua orang mahasiswa terlibat bersama-sama melakukan kegiatan pemeriksaan kesehatan di Pos Pengungsi Cipugur, Desa Cileuksa, Kabupaten Bogor.
Kegiatan ini dilakukan pada tanggal 9 Maret 2020 secara terprogram dalam bentuk penyuluhan dan pelayanan kesehatan kepada masyarakat berusia lanjut yang berada di Pos Pengungsi yaitu pemeriksaan kadar gula darah, asam urat sebagai deteksi dini penyakit deneratif. Lanjut usia (lansia) merupakan tahap akhir perkembangan pada daur kehidupan manusia (Nugroho, 2012). Menurut UU Nomor 13 tahun 1998, batasan usia lansia adalah seseorang yang telah mencapai usia 60 tahun ke atas.

\section{METODE}

Pada kegiatan pengabdian kepada masyarakat ini pemeriksaan gula darah dan asam urat di Pos Pengungsi Cipugur, Desa Cileuksa, Kabupaten Bogor dilakukan tanpa dipungut biaya sebagai wujud pelaksanaan pengabdian masyarakat (Abdimas) dari tim dosen Universitas Gunadarma, Mahasiswa kebidanan dan MAPA bekerja sama dengan Puskesmas Curug, Kabupaten Bogor. Metode yang digunakan sebagai pendekatan pelaksanaan pengabdian masyarakat adalah penyuluhan dan pelayanan kesehatan melalui 
pemeriksaan tes darah Lansia Pos

Pengungsi Cipugur.

Rangkaian tahapan kegiatan pengabdian masyarakat ditunjukkan pada Gambar 1 berikut:

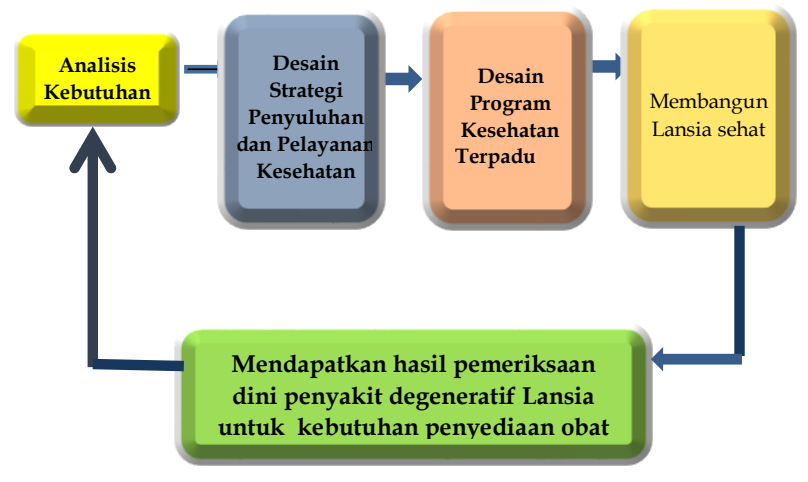

Gambar 1 Metode Pelaksanaan Solusi

Kegiatan pengabdian masyarakat menggunakan cara pemeriksaan kadar gula darah dan asam urat sewaktu (Hilda, T.D Harlita, 2011). Bahan-bahan utama pada kegiatan pengabdian masyarakat ini meliputi bahan utama dan bahan pendukung. Bahan utama dalam pelaksanaan kegiatan adalah sarung tangan, alat monitor kadar gula darah atau kadar asam urat yang dilengkapi batu baterai, tes strip gula darah sewaktu dan asam urat, jarum lanset, alkohol swab dan kapas yang disediakan dalam kapasitas 150 kali tes pemeriksaan. Bahan - bahan pendukung pelaksanaan kegiatan meliputi tiga bagian yaitu alat bantu pemeriksaan, alat tulis dan formulir, konsumsi dan transportasi pelaksanaan kegiatan. Alat bantu pemeriksaana yaitu tiga alat pengukur tekanan darah. Alat tulis yaitu pulpen dan kertas, formulir daftar hadir lansia, formulir rekap kesehatan Lansia. Konsumsi yang berikan kepada para medis dan Lansia. Kendaraan transportasi pelaksanaan kegiatan seperti ambulance dan kendaraan pribadi.

\section{HASIL \& PEMBAHASAN}

Analisis Situasi

Berdasarkan data Survei Penduduk antar Sensus (Supas) 2015, jumlah lanjut usia Indonesia sebanyak 21.7 Juta atau $8,5 \%$. Jumlah masyarakat lanjut usia (lansia) Indonesia pada proyeksi tahun 2019 meningkat menjadi 27.5 juta atau 10,3\%. Proyeksi masyarakat lansia ini semakin meningkat jumlahnya di tahun 2045 yaitu sebesar 57.0 juta jiwa atau 17,9\% (Penduduk Lanjut Usia, 2020). Hal ini dapat diartikan semakin sering terjadi keluhan pada masyarakat lansia (Misnaniarti, 2017) yang dapat dikategorikan sebagai penyakit degeneratif seperti hipertensi, penyakit jantung koroner, diabetes melitus, stroke dan gagal ginjal kronik(Riskesdas, 2018). Penyakit degeneratif merupakan penyakit kronik 
yang dapat mempengaruhi kualitas hidup dan produktivitas manusia (Suiraoka, 2012).

Kegiatan pengabdian kepada masyarakat ini dilakukan bersama Puskesmas Curug, Kecamatan Jasinga, Kabupaten Bogor sebagai mitra kegiatan dengan sasaran kegiatan adalah pengungsi yang berada di Pos Cipugur yang wilayahnya terisolir akibat bencana tanah longsor. Menurut data Puskesmas Curug, terdapat 95 pengungsi berusia lanjut tinggal di relokasi pemukiman. Berdasarkan hasil kegiatan ditemukan identifikasi permasalahan ditempat mitra, untuk melakukan deteksi dini terhadap penyakit degenerative (Nova Fridalni, 2019) dan penyediaan obat yang tepat diperlukan tambahan tenaga medis untuk pemeriksaan di lokasi pengungsi tanpa harus meninggalkan tugas utama sebagai pelayan kesehatan di Puskesmas Curug.

\section{Permasalahan Prioritas Mitra}

Permasalahan paling utama yang dihadapi oleh Mitra yaitu kurangnya sumber daya berupa pelayanan medis(Sulastomo, 2011) yang diperuntukkan bagi pengungsi tanpa harus mengganggu tugas utama
Puskesmas Curug sebagai pelayan medis di Kecamatan Jasinga. Puskesmas Curug merupakan pusat pelayanan kesehatan masyarakat terdekat yang dapat dijangkau oleh pengungsi yang berada di Kecamatan Sukajaya, Kabupaten Bogor(Fallis, 2013). Waktu tempuh perjalanan Puskesmas Curug dan Pos Pengungsi Cipugur, Desa Cileuksa diperkirakan 60 menit dengan jarak tempuh $21 \mathrm{~km}$. Situasi jalan menuju lokasi ini sempit, dengan kondisi kerusakan aspal jalan hampir sepanjang perjalanan menjadikan waktu tempuh menuju lokasi lebih dari 60 menit. Mendekati relokasi pengungsi, perjalanan darat dengan kontur jalan belum beraspal semakin menambah lama waktu tempuh perjalanan.

\section{Dampak Permasalahan}

Kesehatan adalah sangat penting bagi setiap manusia, tanpa terkecuali dengan mereka yang sudah mencapai usia lanjut. Pola hidup sehat seperti menjaga kebersihan diri, kebersihan lingkungan, mengkonsumsi makanan yang sehat dan bergizi serta banyak minum air putih menjadi pilihan bagi setiap orang(Sjahriani et al., 2018)(Almatsier, 2011). Lanjut usia 
merupakan bagian dari proses kehidupan yang tidak dapat dihindari dan akan dialami oleh setiap manusia(Nugroho, 2012).

Pada usia lanjut usia manusia mengalami banyak perubahan baik secara fisik maupun mental, dimana terjadi kemunduran dalam berbagai fungsi dan kemampuan yang pernah dimilikinya. Peningkatan usia sejalan dengan penurunan fungsi organ tubuh sehingga menyebabkan timbulnya beberapa penyakit degeneratif yang umum seperti diabetes mellitus dan penimbunan asam urat(Azis et al., 2020). Diabetes mellitus merupakan penyakit menahun yang ditandai oleh kadar glukosa darah yang melebihi normal dan apabila dibiarkan begitu saja dan tidak terkendali, penyakit ini akan menimbulkan penyakit-penyakit yang berakibat fatal, seperti osteoporosis, hipertensi, penyakit jantung, radang sendi, kanker, diabetes, gangguan pendengaran dan penglihatan (Amelia, 2010)(Khairani, 2012). Deteksi dini terhadap penyakit tersebut dapat dilakukan melalui pemantauan gula darah dengan melihat hasil skrining atau pemeriksaan melalui darah (Nur Isnaini, 2018). Menurut
WHO (World Health Organization), ambang batas kadar normal gula darah dibagi menjadi 4 kelompok, yaitu (World Health Organization, 2015):

1. Ketika puasa : $4-7 \mathrm{mmol} / 1$ atau $72-126 \mathrm{mg} / \mathrm{dL}$

2. 90 menit setelah makan : 10 $\mathrm{mmol} / \mathrm{l}$ atau $180 \mathrm{mg} / \mathrm{dL}$

3. Malam hari : $8 \mathrm{mmol} / \mathrm{l}$ atau 144 $\mathrm{mg} / \mathrm{dL}$

4. Gula darah sewaktu (GDS) : $<140$ $\mathrm{mg} / \mathrm{dL}$

Penyakit degenaratif lainnya pada lansia adalah penyakit asam urat. Tanda dan gejala yang ditimbulkan oleh penyakit ini adalah nyeri secara mendadak di bagian kaki dan biasanya terjadi pada tengah malam, terasa aneh dan kaku pada persendian (Junaidi, 2013)(Sutanto, 2013)(Damayanti, 2013). Asam urat adalah sisa metabolisme zat purin yang berasal dari makanan yang kita konsumsi (Nurhayati, 2018) dan merupakan hasil samping dari pemecahan sel dalam darah. Purin sendiri adalah zat yang terdapat salam setiap bahan makanan yang berasal dari tubuh mahluk hidup (Diantari \& Kusumastuti, 2013). Berbagai sayuran dan buah-buahan juga terdapat purin. Apabila tidak berlangsung secara 
normal maka akan terjadi sebuah proses penumpukan kristal dari asam urat pada persendian sehingga menyebabkan rasa nyeri atau bengkak, kesemutan dan linu. Tes darah merupakan salah satu cara untuk mendeteksi dini penyakit ini yang relatif mudah dan tidak berbiaya mahal. Pemeriksaan lain dapat dilakukan dengan pemeriksaan cairan sendi, tes pencitraan menggunakan X-ray, USG dan CT Scan. Menurut WHO (World Health Organization), ambang batas kadar normal asam urat dibagi menjadi 2 kelompok, yaitu:

1. Laki-laki : $3,5-7,0 \mathrm{mg} / \mathrm{dL}$ 2. Wanita :2,6-6,0 mg/dL Adanya deteksi dini kesehatan pada lansia, maka upaya pencegahan dan pengobatan dapat segera diberikan sehingga tercapai peningkatan derajat kesehatan yang tinggi para lansia. Jika hasil skrining atau pemeriksaan gula darah sewaktu dan asam urat melalui darah menunjukkan nilai diatas ambang batas, maka hasil tersebut dapat dijadikan sebagai peringatan awal untuk perubahan gaya hidup untuk kehidupan yang lebih sehat (Khairani, 2012). Upaya pencegahan dan pengobatan perlu disesuaikan dengan kelompok usia lansia. Batasan umur pada usia lanjut menurut WHO terbagi menjadi 4 kelompok yaitu (Nur Isnaini, 2018):

1. Usia pertengahan (midlle age) antara usia 45 sampai 59 tahun

2. Lanjut usia (elderly) antara usia 60 sampai 74 tahun

3. Lanjut usia tua (old) antara usia 75 sampai 90 tahun

4. Usia sangat tua (very old) diatas usia 90 tahun

Hasil Kegiatan Pengabdian Kepada Masyarakat

Hasil pemeriksaan kesehataan pada 95 orang berusia lanjut ((usia $\geq 45$ tahun) dilakukan berdasarkan rekam data Puskesmas Curug yang menyebutkan terdapat 200 manusia lanjut usia. Deteksi dini penyakit degeneratif pada kegiatan ini dilakukan dengan segmentasi usia $\geq 45$ tahun, sesuai dengan batasan umur pada kelompok usia lanjut paling mendasar. Kegiatan pemeriksaan dilakukan bulan Maret 2020 selama 1 hari, ditujukan untuk mendapatkan hasil pemeriksaan deteksi dini penyakit degeneratif pada lansia Pos Pengungsi Cipugur dengan cepat sehingga kebutuhan penyediaan obat 
dapat diberikan dengan tepat. Tahapan kegiatan terangkum dalam Tabel 1.

Tabel 1 Tahapan Kegiatan Pengabdian Kepada Masyarakat

\begin{tabular}{|c|c|c|c|c|c|c|c|}
\hline \multirow[t]{2}{*}{ No } & \multirow[t]{2}{*}{$\begin{array}{l}\text { Kegiatan Pengabdian } \\
\text { Kepada Masyarakat }\end{array}$} & \multicolumn{6}{|c|}{$\begin{array}{c}\text { Minggu Ke - } \\
\text { (Februari - Juli 2020) }\end{array}$} \\
\hline & & & 3 & 4 & 5 & 6 & 7 \\
\hline \multirow{2}{*}{1} & Koordinasi Dengan & & & & & & \\
\hline & Pihak Terkait & & & & & & \\
\hline \multirow{2}{*}{2} & Observasi kebutuhan & & & & & & \\
\hline & logistik & & & & & & \\
\hline 3 & Mengumpulkan Biaya & & & & & & \\
\hline \multirow{2}{*}{4} & Menghitung biaya & & & & & & \\
\hline & pendistribusian & & & & & & \\
\hline 5 & Pelaksanaan & & & & & & \\
\hline 6 & Menyusun Publikasi & & & & & & \\
\hline \multirow{2}{*}{7} & Menyusun Pelaporan & & & & & & \\
\hline & Kegiatan & & & & & & \\
\hline
\end{tabular}

Berdasarkan Tabel 1, penjelasan terhadap rangkaian kegiatan pengabdian kepada masyarakat secara terperinci meliputi tiga kegiatan,

1. Kegiatan Pendahuluan meliputi tahapan kegiatan ke satu. Pada penelitian ini koordinasi kegiatan dilakukan kepada pihak terkait dan observasi kebutuhan, yaitu mitra kegiatan Abdimas yaitu Puskesmas Curug.

2. Kegiatan Persiapan meliputi tahapan kegiatan ke dua sampai dengan ke empat. Pembiayaan dilakukan secara mandiri dan sukarela oleh semua anggota yang terlibat dalam kegiatan.
3. Kegiatan Pelaksanaan pengabdian kepada masyarakat ini merupakan tahapan ke 5 yang dilakukan selama satu semester yang dimulai sejak bulan Februari sampai dengan bulan Juli 2020.

4. Kegiatan Penutup meliputi tahapan ke enam dan ke tujuh. Pelaporan hasil kegiatan dilakukan setelah keseluruhan rangkaian tahapan telah selesai dilakukan.

Pada kegiatan pengabdian masyarakat ini, kelompok abdimas memberikan informasi tentang tata cara pelaksaan pemeriksaan gula darah dan asam urat sewaktu kepada Lansia yang hadir mengikuti pemeriksaan(Ahmad, 2011)(Safitri A, 2012)(Setiabudi, 2012). Metode pemerilksaan ini sangat mudah disertai dengan alat bantu pemeriksaan, dapat dilakukan di rumah atau di Puskesmas terdekat. Terdapat beberapa merk alat pemeriksaan gula darah dan asam urat yang dapat digunakan, seperti easy touch, autocheck, accu chek dan lain-lain.

Lokasi kegiatan pemeriksaan di lakukan di Ruang Inspirasi Pos Pengungsi Cipugur. Tahap pertama kegiatan ini adalah menyiapkan alat pemeriksaan yaitu alat monitor/mesin 
monitor, tes strip gula darah/ tes strip asam urat, lanset/jarum penusuk, pen lanset, alcohol swab/ kapas alkohol, sarung tangan /handscoon (jika dibutuhkan), bengkok (untuk membuang sampah bekas pemeriksaan), safety box (untuk jarumjarum bekas yang telah digunakan). Pelaksanaan kegiatan pemeriksaan gula darah sewaktu dan asam urat dilakukan dengan tahapan sebagai berikut:

1. Melakukan cuci tangan

2. Gunakan sarung tangan

3. Siapkan alat monitor kadar gula darah/ kadar asam urat.

4. Dilakukan dengan cara memasang baterai serta pasang control cip pada alat monitor. Control cip ini digunakan untuk kalibrasi, jadi setiap botol tes strip akan dilengkapi dengan contol cip.

5. Nyalakan alat monitor dan pastikan bahwa kode di botol harus sesuai dengan kode control cip.

6. Keluarkan tes strip satu, letakkan didekat alat monitor kemudian memasang lanset ke dalam pen lanset.
7. Buka jarum lanset dengan cara putar jarum lanset dan tarik, buang penutup jarum lanset pada bengkok, tutup kembali pen lanset dengan tidak menyentuh jarum lansetnya. Jarum ini hanya digunakan $1 x$, kemudian atur ketajaman jarumnya, dari 1 sampai 5 dimana 5 adalah batas maksimal. Pengaturan jarum lanset tergantung ketebalan kulit.

8. Mengurut jari yang akan ditusuk (darah diambil dari salah satu ujung jari telunjuk, jari tengah, jari manis tangan kiri/kanan).

9. Desinfeksi jari tangan yang akan di tusuk dengan alkohol swab

10. Masukkan tes strip ke dalam tes slot strip pada alat monitor, di monitor akan muncul tanda tetesan

11. Letakkan pen lansetnya dengan mendatar di ujung jari tangan pasien dan biarkan darah mengalir secara spontan, jika darah belum keluar urut-urut daerah tusukan sampai keluar darah. Setelah darah keluar tempelkan strip hingga darah masuk ke pinggir tes strip. 
12. Menutup daerah tusukan dengan alkohol swab.

13. Selanjutnya Perhatikan, alat monitor akan menghitung mundur sampai timer berhenti dan hasil pemeriksaan keluar.

14. Keluarkan tesstrip gula darah/ asam urat yang sudah dipakai dari alat monitor dan buang pada bengkok

15. Matikan alat monitor

16. Membereskan alat (pisahkan jarum bekas dari sampah yang lain dan masukkan jarum bekas ke dalam safety box)

17. Membuka sarung tangan

18. Mencuci tangan

Pemeriksaan asam urat dan gula darah sewaktu dilakukan satu persatu pada warga yang memiliki usia $\geq 45$ tahun dengan menggunakan alat pemeriksaan easy touch, dari sejumlah 95 lansia di Pos Pengungsi Cipugur, hasil pemeriksaan tes darah menunjukkan sebagian besar lansia yaitu 56 orang lansia memiliki hasil pemeriksaan gula darah sewaktu dan asam urat yang tinggi (melebihi nilai normal).

Pembahasan Kegiatan Pengabdian Kepada Masyarakat
Kegiatan penyuluhan dan pelayanan kesehatan Lansia Pos Cipugur dapat terwujud dengan adanya realisasi permintaan dari Puskesmas Curug akan kebutuhan kesehatan untuk pengungsi Lansia yang saat ini menetap di tenda-tenda. Dampak dari bencana longsor di Desa Cileuksa ini telah membuat bergesernya pola hidup pengungsi. Kebutuhan mendesak yang saat ini mereka perlukan tidak hanya kebutuhan primer namun kebutuhan kesehatan.

Strategi dan pogram kegiatan dilakukan terpadu bersama para medis dari Puskesmas Curug dan Puskesmas Sukajaya sebagai jawaban dan respon civitas akademika atas permintaan kebutuhan yang terjadi di lapangan dan merealisasikannya sebagai pelaksanaan kegiatan pengabdian kepada masyarakat. Catatan kesehatan lansia melalui kegiatan pemeriksaan kadar gula darah dan asam urat kemudian diarsipkan untuk kebutuhan penyediaan obat yang tepat.

Pembagian tugas dan wewenang kesehatan Pos Cipugur saat ini dilakukan oleh Puskesmas Sukajaya dan Puskesmas Curug akibat terputusnya jalan darat dari Puskesmas Sukajaya 
menuju lokasi pengungsian. Melalui kunjungan pemeriksaan kesehatan dalam bentuk pengabdian kepada masyarakat, menjadikan Lansia mendapatkan kenyamanan fasilitas kesehatan.

Pemeriksaan kesehatan Lansia pada kegiatan ini memiliki batasan umur pada kelompok usia pertengahan (midlle age) antara usia 45 sampai 59 tahun, dengan menggunakan pemanfaatan alat bantu pemeriksaan gula darah dan asam urat. Berdasarka ambang batas kadar normal gula darah pada kelompok gula darah sewaktu (GDS) yaitu $<140 \mathrm{mg} / \mathrm{dL}$ dan ambang batas kadar normal asam urat pada kelompok laki-laki ( 3,5 - 7,0 mg/dL) dan wanita (2,6 - 6,0 mg/dL) ditemukan hasil bahwa terdapat $50 \%$ Lansia Pos Pengungsi Cipugur memiliki kadar gula darah sewaktu melebih $140 \mathrm{mg} / \mathrm{dL}$ dan kadar asam urat melebihi $6,0 \mathrm{mg} / \mathrm{dL}$ untuk wanita dan $7,0 \mathrm{mg} / \mathrm{dL}$ untuk lakilaki.

Berdasarkan hasil pemeriksaan pada 95 Lansia tersebut, maka tindak lanjut yang berkelanjutan pada pengabdian masyarakat ini adalah memberikan penyuluhan dan penataan kesehatan Lansia untuk mencegah penyakit degeneratif yang berakibat fatal, seperti osteoporosis, hipertensi, penyakit jantung, radang sendi, kanker, diabetes, gangguan pendengaran dan penglihatan (Amelia,2010; Halodoc,2020). Pemberian informasi kesehatan dapat berupa penyuluhan secara rinci pola makan sehat selama di pengungsian dengan memberikan arahan pedoman mengkonsumsi berbagai sayuran dan buah-buahan dengan ambang batas yang dianjurkan untuk mencegah proses penumpukan kristal dari asam urat pada persendian yang dapat menyebabkan timbulnya rasa nyeri atau bengkak, kesemutan dan linu.

\section{SIMPULAN}

Berdasarkan hasil pemeriksaan, pengungsi Pos Cipugur yang memiliki hasil tes pemeriksaan darah dan asam urat tinggi dapat merujuk hasil pemeriksaan ini kepda Puskesmas Curug sebagai pusat pelayanan masyarakat terdekat dari lokasi pengungsi untuk mendapatkan obat sesuai kebutuhan kesehatan. Hal ini berarti, hasil kegiatan pengabdian masyarakat melalui pemantauan kesehatan lansia dengan tes darah sebagai deteksi dini penyakit 
degeneratif di Pos Pengungsi Cipugur

ini, telah dapat membantu Puskesmas

Curug untuk menyediakan obat kepada

lansia yang membutuhkan.

\section{DAFTAR PUSTAKA}

Ahmad, N. (2011). Cara Mudah Mencegah, Mengobati Asam Urat dan Hipertensi. Dinamikamedia.

Almatsier. (2011). Jakarta : Penerbit PT Gramedia Pustaka Utama. Baliwati. In Prinsip Dasar Ilmu Gizi. Jakarta.

Amelia, R. (2010). Dahsyatnya Terapi Herbal untuk Tujuh Penyakit Degeneratif. Pinang Merah.

Azis, W. A., Muriman, L. Y., \& Burhan, S. R. (2020). Hubungan Tingkat Pengetahuan dengan Gaya Hidup Penderita Diabetes Mellitus. Jurnal Penelitian Perawat Profesional. https://doi.org/10.37287/jppp.v2i1.5 2

Damayanti. (2013). Panduan Lengkap Mencegah $\mathcal{E}$ mengobati Asam Urat. Araska.

Diantari, E., \& Kusumastuti, A. C. (2013). Pengaruh Asupan Purin Dan Cairan Terhadap Kadar Asam Urat Wanita Usia 50-60 Tahun Di Kecamatan Gajah Mungkur, SEMARANG. Journal of Nutrition College. https://doi.org/10.14710/jnc.v2i1.209 5

Fallis, A. . (2013). Undang-Undang Republik Indonesia Nomor 13 Tahun 1998 Tentang Kesejahteraan Lanjut Usia Dengan Rahmat Tuhan Yang Maha Esa Presiden Republik Indonesia. Journal of Chemical Information and Modeling. https://doi.org/10.1017/CBO9781107 415324.004

Hilda, T.D Harlita, A. . H. (2011). Pengaruh Waktu Terhadap Hasil Pemeriksaan Kadar Glukosa Darah Pada Penderita Diabetes Melitus. Jurnal Husada Mahakam, Iii( 2), 45-94.

Junaidi, I. (2013). Rematik dan Asam Urat.
In PT Bhuana Ilmu Populer.

Khairani. (2012). Pengetahuan Diabetes Mellitus Dan Upaya Pencegahan Pada Lansia Di Lam Bheu Aceh Besar Diabetic Knowledge and the Prevention of Elderly in Lam Bheu of Aceh Besar Khairani. Idea Nursing Kournal.

Misnaniarti. (2017). Analisis Situasi Penduduk Lanjut Usia dan Upaya Peningkatan Kesejahteraan Sosial di Indonesia. Jurnal Ilmu Kesehatan Masyarakat.

Nova Fridalni, G. (2019). Pengenalan Dini Penyakit Degeneratif. Jurnal Abdimas Saintika.

Nugroho, W. (2012). Keperawatan Gerontik dan Geriatrik. In Jakarta:EGC. https://doi.org/10.1007/s13398-0140173-7.2

Nur Isnaini, R. (2018). Faktor risiko mempengaruhi kejadian Diabetes mellitus tipe dua Risk factors was affects of diabetes mellitus type 2 . Jurnal Kebidanan Dan Keperawatan Aisyiyah.

Nurbowo. (2020). MCK Pilihan. https://wartapilihan.com/mck-yangdirindukan/

Nurhayati. (2018). Hubungan Pola Makan Dengan Terjadinya Penyakit Gout (Asam Urat) Di Desa Limran Kelurahan Pantoloan Boya Kecamatan Taweli. Jurnal Ilmu Kesehatan Masyarakat Kesehatan Masyarakat.

Penduduk Lanjut Usia. (2020). UNFPA Indonesia.

https://indonesia.unfpa.org

Riskesdas. (2018). Hasil Utama Riset Kesehatan Dasar Tahun 2018. Kementrian Kesehatan Republik Indonesia.

Safitri A. (2012). Deteksi Dini Gejala, Pencegahan dan Pengobatan Asam Urat. Penerbit Pinang Merah.

Setiabudi, H. (2012). Deteksi Dini, Pencegahan, dan Pengobatan Asam Urat. Penerbit MedPress (Aggota IKAPI).

Sjahriani, T., Yulianti, T., Kedokteran, D. F., Malahayati, U., Kedokteran, M. F., 
30 Dyah Mieta Setyawati, Sri Hayuningsih, Veronica Farry, \& Sri Supadmini Pemeriksaan Kadar Gula Darah dan Asam Urat Lansia ...

Malahayati, U., \& Gizi, S. (2018).

Hubungan Pola Makan dengan Status

Gizi pada Lansia di UPTD Pelayanan

Sosial Tresna Werdha Natar Lampung

Selatan Tahun 2018. Jurnal Ilmu

Kedokteran Dan Kesehatan.

Suiraoka. (2012). Penyakit Degeneratif. NuhaMedika.

Sulastomo. (2011). Sistem Jaminan Sosial Nasional, Mewujudkan Amanat

Konstitusi. PT. Kompas Media Nusantara.

Sutanto, T. (2013). Deteksi, Pencegahan, Pengobatan asam urat. Buku Pintar.

World Health Organization. (2015). WHO | World report on ageing and health 2015. In World Health Organisation. https://doi.org/10.1016/j.jmgm.2016. 10.012 